\title{
INISIASI PEMBUATAN KEMASAN KOPI UNTUK MENINGKATKAN PEREKONOMIAN DESA ALUN DUA DI KECAMATAN PAGAR ALAM UTARA
}

\author{
Muhammad Hamdan Sayadi1) \\ 1)Fakultas Ekonomi, Jurusan Akuntansi, Universitas Indo Global Mandiri \\ Jln. Jenderal Sudirman No. 629 Km 4, Palembang \\ Email: $\underline{\text { amdansayadi@uigm.ac.id }}^{1)}$
}

\begin{abstract}
ABSTRAK
Perhitungan biaya produksi sangat penting karena berkaitan dengan penentuan Harga Pokok Produksi suatu produk dan penentuan harga jual produk serta dapat mempengaruhi profitabilitas perusahaan. Selain itu, Sistem Tradisional dapat menimbulkan distorsi biaya. Distorsi tersebut dalam bentuk pembebanan biaya yang terlalu tinggi (cost overstate atau cost overrun) untuk produk bervolume banyak dan pembebanan biaya yang terlalu rendah untuk (cost understate atau cost underrun) untuk produk yang bervolume sedikit. Kopi Pagar Alam merupakan salah satu sumber penghasilan masyarakat Sumatera Selatan khususnya Kota Pagar Alam. Pada zaman dahulu, penjualan kopi Pagar Alam masih menggunakan kemasan yang tanpa diberi label. Namun, semakin berkembangnya teknologi membuat masyarakat Pagar Alam semakin cerdik dengan memasarkan produk kopi melalui kemasan yang sudah diberi keterangan berupa nama kopi, sumber dan lain sebagainya. Proses produksi kemasan Kopi Pagar Alam menggunakan berbagai macam tahap sehingga menyerap biaya yang banyak. Oleh karena itu, ketepatan dan kecermatan dalam memproduksi dan memasarkan kopi yang lebih menarik sangat diperlukan untuk menambah penghasilan masyarakat Desa Alun Dua. Proses penyelesaian masalah dilakukan melalui 2 tahap. Tahap pertama ialah menyampaikan ide mengenai pembuatan kemasan produk kopi yang menarik. Tahap selanjutnya membuat kemasan produk kopi yang menarik. Kegiatan ini menggagas ide pembuatan produk kemasan kopi Desa Alun Dua Pagar Alam dan menghasilkan produk kopi yang dikemas dengan tampilan yang menarik dan siap dipasarkan.
\end{abstract}

Kata kunci : Biaya, Pemasaran dan Promosi

\section{PENDAHULUAN}

Indonesia merupakan negara kepulauan yang terdiri dari beraneka ragam suku dan budaya. Beberapa pulau besar di Indonesia antara lain pulau Sumatera, Jawa, Kalimantan, Sulawesi dan Papua. Antara pulau satu dan lainnya memiliki keunikan dan sumber daya alam masing-masing. Salah satu sumber penghasilan masyarakat di Indonesia adalah bercocok tanam. Tanaman-tanaman yang menjadi sumber penghasilan para petani antara lain padi, kopi, coklat dan lain-lain. Akan tetapi, para petani dewasa ini harus menghadapi tantangan berupa perkembangan teknologi.

Perkembangan teknologi dalam pasar global salah satunya berdampak pada para petani. Para petani dituntut untuk dapat memanfaatkan teknologi yang dapat mendukung kinerja perusahaan guna memberikan pelayanan yang terbaik bagi pelanggan. Pemanfaatan teknologi tersebut mengakibatkan biaya operasional yang dikeluarkan perusahaan menjadi besar yang akan berdampak pada Harga Pokok Produksi yang tinggi.

Pesatnya perkembangan teknologi dan informasi juga berpengaruh terhadap proses produksi. Dengan meningkatnya pemakaian mesin-mesin untuk berproduksi yang menggantikan pemakaian tenaga kerja, maka kebutuhan akan tenaga kerja pun berkurang. Dengan meningkatnya penggunaan mesin maka komposisi biaya produksi dalam perusahaan secara perlahan-lahan mengalami perubahan yaitu adanya penurunan Biaya Tenaga Kerja dan kenaikan Biaya Overhead Pabrik. Pembebanan Biaya Bahan Baku dan Biaya Tenaga Kerja Langsung pada produk yang dihasilkan dapat dilakukan dengan tepat dan mudah karena biaya-biaya tersebut dapat dialokasikan secara langsung ke produk jadi, sedangkan pembebanan Biaya Overhead Pabrik pada produk yang dihasilkan perlu 
dilakukan dengan cermat karena biaya ini tidak dapat diidentifikasi secara langsung pada produk sehingga memerlukan metode alokasi tertentu.

Perhitungan Harga Pokok Produksi merupakan semua biaya produksi yang digunakan untuk memproses suatu bahan baku hingga menjadi barang jadi dalam suatu periode waktu tertentu. Ketidaktepatan dalam perhitungan Harga Pokok Produksi membawa dampak yang merugikan bagi perusahaan, karena Harga Pokok Produksi berfungsi sebagai dasar untuk menetapkan harga jual dan laba, sebagai alat untuk mengukur efisiensi pelaksanaan proses produksi serta sebagai dasar untuk pengambilan keputusan bagi manajemen perusahaan. Oleh karena itu, muncul metode baru dalam perhitungan Harga Pokok Produksi yang dikenal dengan nama Activity-Based Costing (ABC) System.

Activity-Based Costing System merupakan metode perbaikan dari Sistem Tradisional. Activity-Based Costing System ini merupakan metode perhitungan biaya yang dapat memberikan alokasi Biaya Overhead Pabrik yang lebih akurat dan relevan. Pada metode ini, seluruh Biaya Tidak Langsung dikelompokkan sesuai dengan aktivitas masing-masing, kemudian masing-masing kelompok biaya (Cost Pool) tersebut dihubungkan dengan masing-masing aktivitas dan dialokasikan berdasar aktivitasnya masingmasing. Dasar alokasi yang digunakan adalah jumlah aktivitas dalam setiap Cost Pool tersebut. Metode ini menggunakan jenis pemicu biaya yang lebih banyak sehingga dapat mengukur sumber daya yang digunakan oleh produk secara lebih akurat.

Ketepatan dan kecermatan dalam menghitung dan membebankannya sesuai dengan jumlah yang telah dikonsumsi oleh aktivitas pembuatan produk sangat diperlukan. Perhitungan biaya produksi sangat penting karena berkaitan dengan penentuan Harga Pokok Produksi suatu produk dan penentuan harga jual produk serta dapat mempengaruhi profitabilitas perusahaan. Selain itu, Sistem Tradisional dapat menimbulkan distorsi biaya. Distorsi tersebut dalam bentuk pembebanan biaya yang terlalu tinggi (cost overstate atau cost overrun) untuk produk bervolume banyak dan pembebanan biaya yang terlalu rendah untuk (cost understate atau cost underrun) untuk produk yang bervolume sedikit.

\subsection{Identifikasi Permasalahan}

Kopi Pagar Alam merupakan salah satu sumber penghasilan masyarakat Sumatera Selatan khususnya Kota Pagar Alam. Pada zaman dahulu, penjualan kopi Pagar Alam masih menggunakan kemasan yang tanpa diberi label. Namun, semakin berkembangnya teknologi membuat masyarakat Pagar Alam semakin cerdik dengan memasarkan produk kopi melalui kemasan yang sudah diberi keterangan berupa nama kopi, sumber dan lain sebagainya. Proses produksi kemasan Kopi Pagar Alam menggunakan berbagai macam tahap sehingga menyerap biaya yang banyak. Oleh karena itu, ketepatan dan kecermatan dalam memproduksi dan memasarkan kopi yang lebih menarik sangat diperlukan untuk menambah penghasilan masyarakat Desa Alun Dua.

\subsection{Tujuan Kegiatan Pengabdian Pada Masyarakat}

Beberapa tujuan dari Program Pengabdian Masyarakat, yaitu:

1. Menginisiasi pembuatan kemasan produk kopi

2. Membuat kemasan produk kopi

\subsection{Manfaat Kegiatan}

Melalui program pengabdian pada masyarakat ini para peserta mampu memahami dan mengetahui mengenai pentingnya membuat kemasan kopi dan menentukan harga jual yang tepat.

\section{METODE PELAKSANAAN PENGABDIAN}

Berdasarkan permasalahan yang telah dijelaskan sebelumnya, proses penyelesaian masalah dilakukan melalui 2 tahap. Tahap pertama ialah menyampaikan ide mengenai pembuatan kemasan produk kopi yang menarik. Tahap selanjutnya membuat kemasan produk kopi yang menarik. 


\section{HASIL DAN PEMBAHASAN}

Program pengabdian kepada masyarakat ini merupakan kolaborasi antara dosen, mahasiswa Fakultas Ekonomi UIGM dan masyarakat Desa Alun Dua. Dosen program studi akuntansi Muhammad Hamdan Sayadi, SE., M.Acc dan para mahasiswa menggagas ide mengenai ide pembuatan kemasan kopi Desa Alun Dua Pagar Alam dan memasarkannya melalui media sosial seperti Instagram. Pemasaran melalui media sosial dapat membantu konsumen memesan produk kopi dengan sangat mudah. Pemasaran melalui media sosial juga dapat meningkatkan penghasilan masyarakat Desa Alun Dua.

\subsection{Akuntansi Biaya}

\section{Definisi Akuntansi Biaya}

Akuntansi biaya didefinisikan sebagai suatu proses mengidentifikasian, mendefinisi, mengukur, melaporankan, dan menganalisis berbagai unsur beaya lamgsung dan tidak lagsung yang berkaitan dengan proses menghasilkan dan memasarkan produk (Riwayadi dalam Putri dan Handayani, 2017).

2. Tujuan dan Manfaat Akuntansi Biaya

Tujuan dari akuntansi biaya memberikan informasi yang akurat bagi perusahaan. Informasi tersebut nantinya akan digunakan sebagai pertimbangan dalam proses pengambilan keputusan. Akuntansi biaya mempunyai tiga tujuan pokok yakni menentukan biaya produksi, mengendalikan biaya, dan mengambil keputusan khusus (Mulyadi dalam Putri dan Handayani, 2017).

Manfaat akuntansi biaya secara luas dianggap sebagai cara perhitungan nilai persediaan yang dilaporkan di neraca dan angka harga pokok penjualan yang disajikan di laporan laba rugi. Akuntansi biaya melengkapi manajemen dengan alat yang diperlukan untuk aktivitas perencanaan dan pengendalian, perbaikan kualitas dan efisiensi, pengambilam keputsan yang baik yang bersifat rutin dan yang bersifat startegik (Carter dalam Putri dan Handayani, 2017).

\subsection{Sistem Akuntansi Biaya Konvensional}

Akuntasi beaya konvensional atau tradisional hanya membebankan biaya produksi ke produk, sedangkan biaya lain yang berkaitan dengam porduk seperti beaya peneltian dan pengembagan, beaya pemasaran, beaya distribusi, dan beaya layanan pelanggan tidak dibebankan ke harga pokok produk (Riwyadi dalam Putri dan Handayani, 2017)

\subsection{Activity Based Costing}

Activty Based Costig adalah suatu metode yang megukur biaya porduk atau jasa yang berdasarkan atas penjumlaham biaya (cost acummulation) dari pada kegiatannatau aktivtas yang timbul berkaitam degan produksi atau jasa tersebut (Witjaksono dalam Putri dan Handayani, 2017).

\subsection{Kelebihan dan Kelemahan}

Kelebihan metode $\mathrm{ABC}$ adalah biaya produk yang dihasilkan menjadi lebih akurat serta memberikan perhatian pada semua aktivitas yang terjadi, sehingga semakin banyak beaya tidak langsumg yang dapat ditelusuri pada objek biaya (Dunia, 2012:329). Menurut Witjaksono (2013:243), kelemahan metode $\mathrm{ABC}$ adalah dalam penerapannya memerlukan lebih banyak, waktu, tenaga, dan juga peralatan, sehingga menghasilkan informasi dengan biaya yang relatif lebih mahal dibandingkan infromasi yang dihasilkan oleh sistem akuntansi biaya konvensional atau tradisional.

\subsection{Kemasan Kopi Desa Alun Dua Kota Pagar Alam}

Kemasan produk khususnya kopi harus dibuat secara menarik dan elegan. Para konsumen secara umum menilai kualitas suatu produk dari kemasa luarnya. Program pengabdian kepada masyarakat ini menghasilkan kemasan produk yang menarik. 

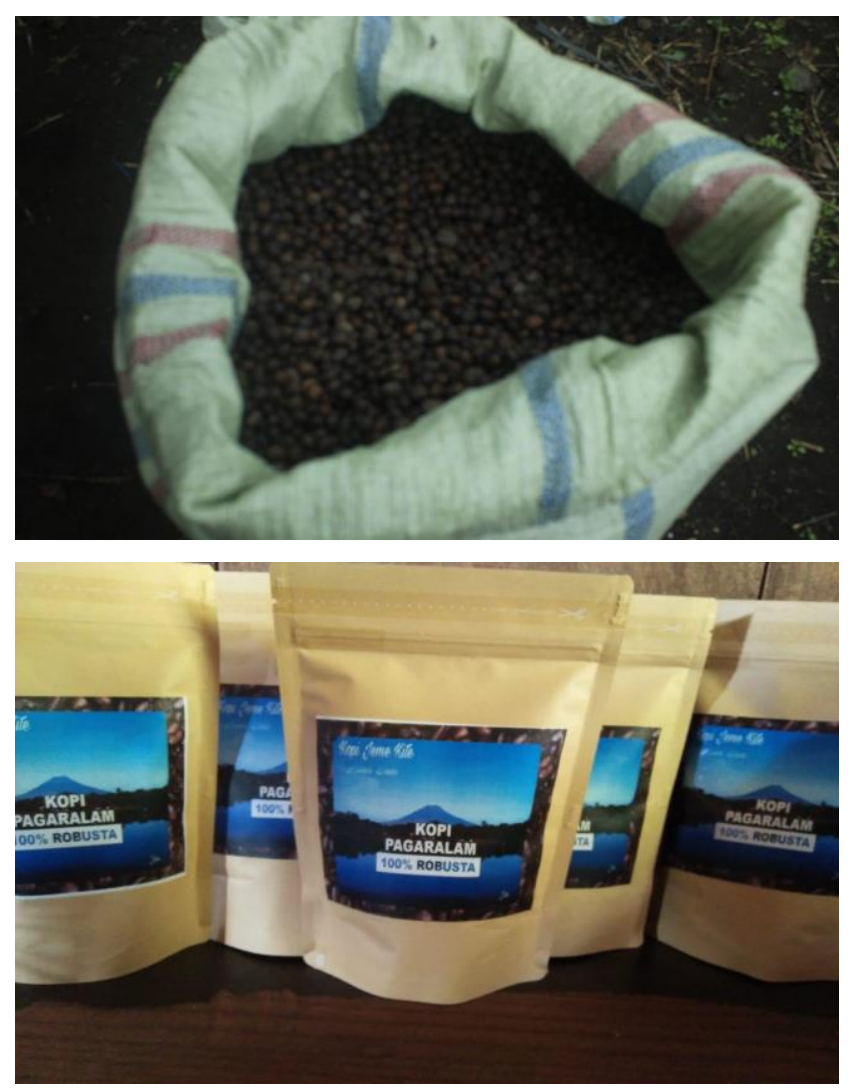

Gambar 1. Kemasan Produk Kopi Desa Alun Dua Pagar Alam

\subsection{Strategi Meningkatkan Perekonomian Desa}

Beberapa tahap yang dapat dilakukan untuk meningkatkan perekonomian Desa Alun Dua melalui produk kopi, yaitu:

1. Membuat kemasan produk kopi yang menarik

2. Melakukan penjualan melalui media sosial seperti Instagram.

3. Menjalin hubungan baik dengan konsumen.

\section{KESIMPULAN DAN SARAN}

\subsection{Kesimpulan}

1. Kegiatan ini menggagas ide pembuatan produk kemasan kopi Desa Alun Dua Pagar Alam

2. Produk kopi dikemas dengan tampilan yang menarik dan siap dipasarkan.

\subsection{Saran}

1. Membuat kemasan produk yang menarik untuk barang berupa makanan.

2. Melakukan penjualan melalui media sosial seperti Instagram.

3. Menjalin hubungan baik dengan konsumen.

\section{UCAPAN TERIMA KASIH}

Penulis menyampaikan ucapan terima kasih yang sebesar-besarnya atas kerjasama dalam pelaksanaan kegiatan ini kepada :

1. Fakultas Ekonomi UIGM

2. Lembaga Penelitan dan Pengabdian Masyarakat UIGM

3. Ketua RT 01 dan 02 Alun Dua dan masyarakat Desa Alun Dua Pagar Alam

4. Para Mahasiswa Prodi Akuntansi dan Manajemen. 


\section{DAFTAR PUSTAKA}

Damayanti, Damayanti., Astuti, Widi, dan Putri RDA. 2019. Peningkatan Nilai Tambah Daun Kersen (Muntingia Calabura L.) Menjadi Permen Jelly dan Teh Seduh. Jurnal Pengabdian Kepada Masyarakat Universitas Negeri Semarang.

Kusmuriyanto, K., Feriady, M, dan Susilowati, N. 2019. Inisiasi Pembentukan BUMDES Bersama Untuk Meningkatkan Perekonomian Desa Di Kecamatan Jambu Kabupaten Semarang. Jurnal Pengabdian Kepada Masyarakat Universitas Negeri Semarang.

Putri, Nanda Desika dan Handayani Siti Ragil. 2017. "Analisis Perbandingan Metode Konvensional dan Metode Activity Based Costing (ABC) untuk Tarif Rawat Inap". Jurnal Administrasi Bisnis Universitas Brawijaya. 